\title{
JUST COMPENSATION AND THE PUBLIC CONDEMNEE
}

State and local governments, like private owners, are protected by the Fifth Amendment's just compensation clause against federal takings of property. ${ }^{1}$ Courts thus must determine "full, fair, and adequate compensation" for bridges, schools, and other public facilities when taken by the federal government. The usual standard of "just compensation" for private parties-market value ${ }^{2}$-is often inappropriate, since there is no ready market for such facilities as bridges. ${ }^{3}$ Even when the public property has a market value, that standard is often inadequate. Community needs or desires may require a local government to replace the lost facility at a cost far higher than market value compensation provides.

Courts have developed the substitute facility doctrine to meet the unique needs of public condemnees; damages will be awarded suffcient to finance a replacement. 4 They have, however, qualified this rule by holding that it is applicable only if a replacement is "necessary." Some courts have demanded in addition that the necessity be "legally compelled," and have granted compensation to replace only those facilities which the state or municipality was legally obligated to provide. 5 The legal obligation formula developed from cases where

1. See, e.g., Jefferson County v. TVA, 146 F.2d 564 (Gth Cir.), cert. denied, 324 U.S. 891 (1945); Town of Nahant v. United States, 136 Fed. 273 (1st Cir. 190J).

2. United States v. Cors, 337 U.S. 325,332 (1949); United States ex rel. TVA v. Powelson, 319 U.S. 266, 275 (1943); United States v. Miller, 317 U.S. 369, 374 (1913).

The term "market value," as used here, includes the concept of reproduction cost less depreciation in instances where the courts have determined that just compensation requires this measure of indemnification for existing structures in addition to the market value of the underlying land. See generally 2 ORGer, Valuanon UNder EMINENT DoNaiN \$ 188-99 (1953).

3. E.g., United States v. Board of Education, 253 F.2d 760 (4th Cir. 19j8) (school property); Mayor and City Council v. United States, 147 F.2d 706 (4th Cir. 1945) (land set aside for streets and alleys); United States v. 1,433 Acres of Land, 71 F. Supp. 854 (D. Kan. 1947) (roads and highways). Contra, United States v. South Dakota Game, Fish and Parks Dep't, 329 F.2d 665 (8th Cir.), cert. denied, 379 U.S. 900 (1965) (public park); Nebralia v. United States, 164 F.2d 866 (8th Cir. 1947) (school lands); Westchester County Park Comm'n v. United States, 143 F.2d 688 (2d Cir. 1944) (county lands).

4. E.g., United States v. Certain Lands, 246 F.2d 823 (3d Cir. 1957); City of Fort Worth v. United States, 188 F.2d 217 (5th Cir. 1951); United States v. Arkansas, 164 F.2d 943 (8th Cir. 1947); United States v. Los Angeles County, 163 F.2d 124 (9th Cir. I917); United States v. 0.886 of an Acre of Land, 65 F. Supp. 827 (E.D.N.Y. 1940).

5. E.g., United States v. Wheeler Township, 66 F.2d 977, 985 (8th Cir. 1933); United States v. Alderson, 53 F. Supp. 528 (S.D.W. Va. 1944); cf. California v. United States, 169 F.2d 914, 924 (9th Cir. 1948).

The legal compulsion test has been most readily applicable in instances where condemnees were institutions of county or municipal government, and where standards for 
tracts of private land were condemned by the federal government along with their publicly-owned access roads. ${ }^{6}$ New access roads would have been useless to the local government. Courts, however, held that the federal government was freed of any obligation because the roads were not legally required. This epithet has worked subsequent mischief. Compensation has been denied for substitutes that were useful but not required by statute.

The "necessity" test, even when not compounded by the adjective "legal," is harsh and uncertain. Consider the recent Second Circuit decision in United States v. Certain Land in the Borough of Brooklyn.7 New York City owned a tract of 55,000 square feet, having condemned the land and its improvements in order to build a school and a playground. After the city had relocated the tenants, leveled the improvements, and nearly completed the school, the United States decided to expand an adjacent post office onto 15,000 square feet of playground land.

The District Court awarded the city only the market value of the land rather than the cost of a new playground. The Court of Appeals reversed, ordering the District Court to determine:

whether a new playground is in fact necessary, how much land would be needed if it is, the expense involved in such a project, whether the ... [remaining land] could be part of the substitute, and what is its value. ${ }^{8}$

The District Court had conceded that "the Board of Education is required by law to provide a playground,"9 but thought the statute could be satisfied by using the remaining land. The Court of Appeals however said the necessity rule "looks to the pragmatic needs and possibilities, not just to the technical legal minima." 10

the provision of community services by these institutions have been set out by their state governments. Thus in United States v. Board of Education, 258 F.2d 760 (4th Cir. 1958). where the federal government condemned a portion of a school playground, the court alluded to a requirement of West Virginia's State Board of Education that high schools of the character involved have a certain minimal size playground in holding that the substitute facility doctrine should be applied.

6. E.g., United States v. Alderson, 53 F. Supp. 528 (S.D.W. Va. 1944). In Woodville v. United States, 152 F.2d 735 (10th Cir. 1946), where the federal government condemned an entire town in connection with its construction of a dam and reservoir, the court most reasonably held that the town government had been relieved of its obligation of provid. ing public ways, thus denying compensation. Maintaining its perspective to the very end, the court also noted parenthetically that the town no longer existed.

7. 346 F.2d 690 (2d Cir. 1965).

8. Id. at $695-96$.

9. Id. at 695 .

10. Ibid. 
While the Second Circuit recognized, as had some prior courts, 11 that legal compulsion provides no measure of community' needs, it adhered to the broad rule that only "necessary" facilities need be replaced by the federal government. The issue, however, of what kinds of public projects are "in fact" necessary is one peculiarly unsuited for judicial determination. What equipment is "in fact" necessary for a playground? How many basketball courts do junior high school students really need? To talk of the "necessity" of such facilities misses the crucial point. The politically responsible branches of state and local government have already determined that it is in the interests of the community to have such facilities. They have provided them for their citizens; and a federal taking means that these services are no longer available. For a federal court to override local judgment by determining that such services are not necessary is an unjustified interference with political decisions.

Federal courts, rather, should ask only whether a proposed substitute would serve a rational governmental purpose.

The proposed approach is neither as confining as "legal necessity" nor as enigmatic as "factual necessity." Moreover, it would respect established local policies. For example, a municipality may own a piece of land on which it plans to construct a football stadium rather than a new school or some other facility. The local government may make that decision though it has a statutory duty to provide schools and none to provide football stadiums. Federal courts ought not to weigh the "necessity" of such a facility, but should yield to the judgment of community interest determined by the institution peculiarly suited to make it.

Deference to local decisions should not become a reflex. District courts must answer several important questions before they award the cost of a substitute facility. First, the local government must show a public purpose. If the seized property was unused, the condemnee would have to show in specific legislative or administrative acts, such as authorization or appropriation of construction funds, its plans for the property's use. ${ }^{12}$ Vague speculation should not support a compensa-

11. See, e.g., United States v. Des Moines County, 148 F.2d 488 (8th Cir.), cert. denied, 326 U.S. 743 (1945). Courts sometimes do not even refer to a legal compulsion test, tresting the question of necessity as factual. See, e.g., United States v. City of New York, 168 F.2d 387 (2d Cir. 1948), affirming United States v. 25.4 Acres of Land, 71 F. Supp. 255 (E.D.N.Y. 1947).

12. The existence of plans for a future facility does not, of course, require the United States to pay the entire cost of construction. Rather, the damages awarded should be sufficient to replace the land taken, and to bring the plans for the new facility to an equivalent stage of development. 
tion award. ${ }^{13}$

Second, the governmental purpose must meet a threshold standard of rationality. In most cases this will be no obstacle. Occasionally, however, the cost of a proposed substitute may be grossly disproportionate to its utility. Washington $v$. United States, ${ }^{14}$ is a possible example. In that case the federal government condemned twenty-eight miles of a gravel secondary highway connecting the towns of Connel and Yakima. The court found that only about ten cars a day had traveled the condemned highway and that only about a dozen people in the two towns needed a substitute road. Moreover, the traffic load could be borne by two other roads, longer in distance but not in traveling time. The court dismissed as irrelevant state desirability and convenience studies and refused to award the cost of a substitute road. ${ }^{15}$

If the court had applied the proposed governmental purpose test, the state would be presumed to be pursuing legitimate public policies and thus entitled to the compensation award. But the presumption would not be conclusive. If the federal government could prove that existing alternate routes would bear the load of the condemned road without significant added cost to either the state or the motorists and

An interesting illustration of the problems a court might face in determining whether such plans exist is to be found in United States v. 51.8 Acres of Land, 151 F. Supp. 631 (E.D.N.Y. 1957), aff'd sub nom. United States v. Jones Beach State Parkway Authority, 255 F.2d 329 (2d Cir.), cert. denied, 385 U.S. 832 (1958). The federal government con. demned a tract of unimproved land adjacent to Mitchell Air Force Base in which it already held an aviation easement. The state, noting that "the land was acquired and held under legislative authority for parks and parkways," 151 F. Supp, at 695, asked that the land should be valued for "park use," in essence requesting an application of the substitute facility doctrine. The district court denied this request, finding; that the circumstances of the state's acquisition of the land at the behest of the federal government belied its claim of park use; that the land involved had never been used for park or recreational purposes, and that the legislature had, before the date of taking, authorized the Parkway Authority to "sell, exchange or otherwise dispose of this land." Id. at 636. The court awarded market value. On appeal, the Second Circuit apparently failcd to perceive the nature of the state's claim. Rather than confronting the substitute facility doctrine, it merely held that the award of the district court should be affirmed because the state had failed to introduce evidence to prove that the "highest and best use" of the land was for park purposes. It thus accepted the application of a market valuc standard without question. Although the result was probably correct, only the lower court even tangentially recognized the real problem in the case.

13. See Mayor and City Council v. United States, 147 F.2d 786 (4th Cir. 1945), wherc the court held that the valuation of condemned property was unchanged by the fact that the City of Baltimore might some day want to construct a sewage system beneath the condemned public streets and alleys in which it held easements. See also United States v. Benedict, 280 Fed. 76, 82 (2d Cir. 1922).

14. 214 F.2d 33 (9th Cir.), cert. denied, 348 U.S. 862 (1954).

15. 214 F.2d at 45 . 
that the road served no aesthetic or other unique function, the court might find a replacement irrational and deny compensation.

Insistence that proposed replacements show only threshold rationality shifts the burden to the federal government to demonstrate not only that the facility is not necessary, but that it is not desirable, convenient, attractive or otherwise beneficial. Only when this burden is met may a court override local decisions.

Third, the court must assess the amount of compensation due. As in the past, the courts should not require the United States to pay to reproduce exactly the seized facility, ${ }^{16}$ but only to provide an equally useful substitute. ${ }^{17}$ Thus, in the Brooklyn playground case, ${ }^{18}$ the federal government would not have to provide land on the same side of the school as the remaining playground land if it could more cheaply provide an equally useful tract on the other side of the building. ${ }^{10}$

Often the new federal project will help the affected community more than the facility it displaces. Rarely, however, should this benefit be subtracted from the required compensation. The federal project will seldom serve the same purpose as the condemned facility..$^{\circ}$ In the Brooklyn case, for example, a post office displaced a playground. However, when the federal government provides an adequate substitute for the community facility as part of its own project, the state should not receive the cost of a replacement if the federal substitute is equally useful. ${ }^{21}$ The state cannot claim that local policies have been frustrated

16. It should be noted here that where the substitute facility doctrine is applicable, the federal government must not only pay damages sufficient to provide a physial substitute for the property taken, but is also liable for the cost of providing the services offered by that property, where possible, until the new facility is constructed.

17. United States v. Certain Land, 192 F. Supp. 725, 726-27 (N.D. Cal. 1961). See also Gity of Fort Worth v. United States, 188 F.2d 217 (5th Cir. 1951); Jefferson County v. TVA, 146 F.2d 564 (6th Cir.), cert. denied, 324 U.S. 871 (1945).

18. See text accompanying notes 7-10, supra.

19. The city could demonstrate, of course, that contiguous land was needed to provide softball fields or other facilities desirable for a playground.

20. Concededly, the federal government will find it easier than usual to challenge the rationality of replacement if the federal facilitics planned for operation can meet all of the varied needs and interests serred by the condemned facility.

21. The Supreme Court recognized in Brown v. United Statcs, 263 U.S. 78 (1923), that the federal government could indemnify a public condemnce by comdemning private property and conveying such property to the public condemnee. (The case arose on the private condemnee's contention that the condemnation of his property was not for a "public purpose" and was therefore unconstitutional.) Thus in Jefferson County v. TVA. I46 F.2d 564 (6th Cir.), cert. denied, 324 U.S. 871 (1945), the Court of Appeals held that the United States had satisfied its constitutional obligation of just compensation by building a new highway system of equal utility to replace the one it had taken.

Situations may arise where the federal government does provide a substitute facility 
when those policies are accommodated within the federal project. When public property not being put to a rational governmental use is sold, the state stands in the position of a private owner and is entitled to market value. ${ }^{22}$ Even when the property is serving a rational governmental purpose, market value at times will be higher than replacement cost. ${ }^{23}$ If the property had not been condemned, the state could have sold it, built a new facility, and kept the difference. Federal condemnation should not deprive the state of such profits. Since indemnification is designed to put the owner of property in the same position he was in before condemnation, market value should be awarded in such cases. ${ }^{24}$

Market value may be a useful tool for court supervision of awards. Decrees must be framed to prevent public condemnees from keeping their awards without building substitute facilities. The federal condemnation statute ${ }^{25}$ allows courts to prevent windfalls by holding awards in trust and ordering further deposits by the United States when they are needed. ${ }^{26}$ Courts can use this statutory power to limit payments to market value until the public condemnee demonstrates that the extra money will be used to provide a new facility. ${ }^{27}$

in connection with its condemnation, but where a court finds that the substitute does not meet the test of equal utility. Under such circumstances, insofar as this new facility decreases the expense that the state will have to undergo in providing a substitute of equal utility, it should be permitted to offset the award which would have been due the state had the United States not attempted this manner of indemnificaion.

22. In United States v. Certain Lands, 47 F. Supp. 96 (S.D.N.Y. 1944), the federal government condemned an old school house which was no longer being used. The court awarded the school district the market value of its property. Since there was no longer an identifiable governmental purpose for the district's ownership of the school, this result was correct.

23. This is often likely to be the case in urban areas where public facilities occupy land which is particularly desirable for commercial purposes.

24. Contra, United States v. Des Moines County, 148 F.2d 448 (8th Cir.), cert. denied, 326 U.S. 743 (1945), where in remanding to the district court for a determination of the factual necessity of a substitute facility, the court held that if such necessity existed, the award would be determined by the substitute facility doctrine, regardless of market valuc.

25. 46 Stat. 1421 (1931), 40 U.S.C. § 258a (1964).

26. See United States v. 15.3 Acres of Land, 158 F. Supp. 122 (M.D. Pa. 1957). The most frequently manifested purpose of such regulation is to prevent fec owners from automatically receiving entire condemnation awards, to the prejudice of lienholders. Sce, e.g., John Hancock Mut. Life Ins. Co. v. Casey, 147 F.2d 762 (1st Cir. 1945); Thibodo v. United States, 134 F. Supp. 88 (S.D. Cal. 1955). In United States v. Certain Lands, 89 F. Supp. 91, 99 (E.D.N.Y. 1941), the court noted: "If it should appear in a condemnation proceeding that the applicant is not entitled to the entire deposit, the court may nevertheless award him the part to which he is entitled. ..."

27. In Thibodo v. United States, sispra note 26 , at 97 , the court said:

Even the deposit by the Government of its estimate of the value, does not automatically pass to the owners of the property or those having an interest in it. Thcy can only withdraw such portion of it as the Court might approve. (Emphasis in original.) 